\title{
RESEARCH IN SPORT \\ PHYSICALACTII \\ Different expression tones of central and peripheral endocannabinoids levels in overweight and obese mice
} \author{
$\begin{array}{ll}\text { Autor(es): } & \text { Wang, Ru; Qin, Yang; Qianqian, Tian; Shunli, Sun; Wei, Liu; Xiangdong, } \\ \text { Sun; Na, Li }\end{array}$
}

Publicado por: Imprensa da Universidade de Coimbra

URL

persistente:

URI:http://hdl.handle.net/10316.2/44155

DOI:

DOI:https://doi.org/10.14195/2182-7087_ex2018_92

Accessed : $\quad$ 26-Apr-2023 05:13:27

A navegação consulta e descarregamento dos títulos inseridos nas Bibliotecas Digitais UC Digitalis, UC Pombalina e UC Impactum, pressupõem a aceitação plena e sem reservas dos Termos e Condições de Uso destas Bibliotecas Digitais, disponíveis em https://digitalis.uc.pt/pt-pt/termos.

Conforme exposto nos referidos Termos e Condições de Uso, o descarregamento de títulos de acesso restrito requer uma licença válida de autorização devendo o utilizador aceder ao(s) documento(s) a partir de um endereço de IP da instituição detentora da supramencionada licença.

Ao utilizador é apenas permitido o descarregamento para uso pessoal, pelo que o emprego do(s) título(s) descarregado(s) para outro fim, designadamente comercial, carece de autorização do respetivo autor ou editor da obra.

$\mathrm{Na}$ medida em que todas as obras da UC Digitalis se encontram protegidas pelo Código do Direito de Autor e Direitos Conexos e demais legislação aplicável, toda a cópia, parcial ou total, deste documento, nos casos em que é legalmente admitida, deverá conter ou fazer-se acompanhar por este aviso. 


\section{ANNALS OF RESEARCH IN SPORT AND PHYSICAL ACTIVITY}




\section{DIFFERENT EXPRESSION TONES OF CENTRAL AND PERIPHERAL ENDOCANNABINOIDS LEVELS IN OVERWEIGHT AND OBESE MICE}

Wang Ru¹, Qin Yang1', Qianqian Tian¹, Shunli Sun'1, Wei Liu', Xiangdong Sun¹, Na Li

KEYWORDS: Endocannabinoids; overweight; obesity

\section{INTRODUCTION}

Overweight and obesity are associated with activation of the endocannabinoid system ${ }^{(1)}$. However, it is not clear whether there is a different expression tone of the endocannabinoids (ECs) between the overweight and obese groups. We assume that endocannabinoids 2-arachidonoylglycerol (2-AG), Anandamide (AEA) and N-oleylethanolamine (OEA) levels are higher in the brain and serum of obese individuals than in overweight groups.

\section{PURPOSE}

To explore the differences of ECs levels in central and peripheral between overweight and obese mice fed on a high fat diet and to analyze the relationship between ECs and body fat ratio.

\section{METHODS}

C57BL/6J male mice, at four weeks old, were randomly divided into control group ( $n=25$, fed normal diet) and high fat diet group ( $n=205$, fed D12492, 60\% fat) by EXCEL random grouping table. After an 8-week of follow-up, 10 mice were randomly selected

1 Shanghai University of Sport.

Email: wangru0612@163.com; yangqinsus@163.com 
from the control group, and their average body weight (BW) was defined as $X{ }^{(g)}$. Then the mice fed on high fat diet were divided into two groups based on their BWs as compared to X: overweight (110-119\% X) and obese (120-149\% X) group. High performance liquid chromatography (HPLC) were used to detect endocannabinoids levels (including 2-AG, AEA, OEA $)$. Body fat ratio $=($ Perirenal and epididymal fat mass $) / B W * 100 \%$. Data were shown as mean \pm standard deviation (SD) and independent $t$ test was used to analyze ECs levels between two groups. $\mathrm{P}<0.05$ was considered to be significant.

\section{RESULTS}

1) Serum 2-AG, AEA and OEA were higher in obese group (141.55 $\pm 89.90 ; 21.54 \pm 12.96$; $63.44 \pm 42.27)$ than in overweight group mice $(116.09 \pm 126.91 ; 19.72 \pm 18.96 ; 43.23 \pm 37.15$, respectively, unit: $\mathrm{pg} / \mathrm{ml})$, although statistical significances were not reached $(P>0.05$, for each comparison); 2) Brain tissue AEA and OEA in obese group $(0.43 \pm 0.12 ; 0.68 \pm 0.19)$ were significant higher than overweight group $(0.31 \pm 0.10 ; 0.49 \pm 0.10 ; P<0.05$ and $P<0.01$ respectively, unit: ng/mg); 3) Taken overweight and obese group as a whole $(n=20)$, we found brain tissue OEA showed a positively relationship with BW $(r=0.376, P<0.05)$ and body fat ratio $(r=0.427, P<0.05)$.

\section{CONCLUSION}

Central and peripheral ECs show a rising trend as body weight gains and OEA may be more relevant to the increase in fat mass.

\section{ACKNOWLEDGEMENTS}

This work was supported by National Natural Science Foundation of China (NSFC grant number: 81472148).

No potential conflicts of interest relevant to this abstract were reported.

\section{REFERENCE}

1. Silvestri, C., Ligresti, A. \& Di Marzo, V. 2011. Peripheral effects of the endocannabinoid system in energy homeostasis: adipose tissue, liver and skeletal muscle. Rev Endocr Metab Disord, 12, 153-62. 